\title{
Hubungan Antara Job Insecurity Dengan Burnout Pada Karyawan Outsourching Fifgroup Cabang Padang
}

\author{
Asroni Rasip, Harri Kurniawan, Isna Asyri Syahrina \\ Fakultas Psikologi, Universitas Putra Indonesia "YPTK" Padang, Indonesia \\ Email: asronirasip@gmail.com, arikkurniawan17@gmail.com, @Isnasyeko@gmail.com
}

\begin{abstract}
This study aims to determine the relationship between job insecurity with burnout on FIFGROUP Padang outsourching employees. The independent variable in this study is job insecurity and the dependent variable is burnout. The measuring instrument used in this study uses a saturated sample technique. The sample in this study was 40 employees of FIFGROUP outsourching Padang branch. The validity and reliability test in this study uses the Cronbach Alpha technique. The results of the validity coefficient on the job insecurity scale move from rix $=0.305$ to rix $=0.706$ with a reliability coefficient of $\alpha=$ 0.884 . While on the burnout scale move from rix $=0.373$ to rix $=0.737$ with a reliability coefficient of $\alpha=0.915$ Based on data analysis, obtained correlation value of 0.406 with a significance level of 0.009 which means the hypothesis is accepted. This shows that there is a significant relationship between job insecurity with burnout on Padang branch FIFGROUP outsourching employees.
\end{abstract}

Keywords : job insecurity, burnout, outsourching employees.

\begin{abstract}
Abstrak
Penelitian ini bertujuan untuk mengetahui hubungan antara job insecurity dengan burnout pada karyawan outsourching FIFGROUP cabang Padang. Variabel Bebas dalam penelitian ini adalah job insecurity dan variabel terikat adalah burnout. Alat ukur yang digunakan dalam penelitian ini menggunakan teknik sampel jenuh. Sampel dalam penelitian ini adalah 40 orang karyawan outsourching FIFGROUP cabang Padang. Uji validitas dan reliabilitas pada penelitian ini menggunakan teknik Alpha Cronbach. Hasil koefisien validitas pada skala job insecurity bergerak dari rix =0,305 sampai dengan rix $=$ 0,706 dengan koefisien reliabilitas sebesar $\alpha=0,884$ Sedangkan pada skala burnout bergerak dari rix $=0,373$ sampai dengan rix $=0,737$ dengan koefisien reliabilitas sebesar $\alpha=0,915$ Berdasarkan analisis data, diperoleh nilai korelasi sebesar 0,406 dengan taraf signifikansi 0,009 yang berarti hipotesis diterima. Hal ini menunjukkan bahwa ada hubungan yang signifikan antara job insecurity dengan burnout pada karyawan outsourching FIFGROUP cabang Padang.
\end{abstract}

Kata kunci : job insecurity, burnout, karyawan outsourching.

\section{Pendahuluan}

Bekerja merupakan hal yang harus dilakukan oleh seseorang untuk memenuhi kebutuhan sehari-hari dan juga sebagai identitas diri bahwa mereka bukan pengangguran yang hanya tidur-tiduran di rumah, namun untuk mendapatkan pekerjaan tidak semudah membalikan telapak tangan perlu skil dan ilmu yang cukup serta pendidikan yang tinggi juga mempengaruhi seseorang dalam mendapatkan pekerjaan sepertihalnya untuk bekerja diperusahaan biasanya dibutuhkan ijazah S1 sebagai syarat minimal untuk melamar sebagai karyawan pada perusahaan tersebut. Walaupun banyak alat teknologi yang semakin canggih di zaman sekarang ini akan tetapi perusahaan juga masih memerlukan para karyawan untuk tetap melanjutkan aktivitas organisasinya (dalam Markus dan Jatmika, 2017).

Dalam menjalankan tugasnya sebagai karyawan mereka dituntut untuk dapat bekerja dengan tuntutan pekerjaan yang tinggi, jam kerja yang melebihi batas waktu kerja yang biasanya sehingga tidak jarang membuat para karyawan merasa kelelahan baik dari segi fisik maupun psikis. Salah satu persoalan yang muncul yang berkaitan dengan diri individu di dalam menghadapi tuntutan pekerjaan yang semakin tinggi dan persaingan yang keras ditempat kerja karyawan itu adalah stres.

Stres dapat terjadi kapan saja dan bersumber dari mana saja, yaitu dari setiap aspek dalam kehidupan manusia, Sarafino (dalam Mariyanti dan Citrawati, 2011). Stres yang berlebihan akan berakibat buruk terhadap kemampuan individu untuk berhubungan dengan lingkungan secara normal. Stres yang dialami individu dalam jangka waktu yang lama dengan intensitas yang cukup tinggi akan mengakibatkan individu yang bersangkutan menderita kelelahan, baik fisik ataupun mental, keadaan seperti ini disebut Burnout. Burnout, adalah sindrom stres yang ditandai dengan kelelahan, detasemen kerja, dan berkurangnya pencapaian pribadi. Burnout hasil dari periode stres berkepanjangan dan dari ketidakmampuan untuk mencapai tujuan pribadi. (Hardiyanti, 2013).

Diterima Redaksi: 13-02-2020 | Selesai Revisi: 2-05-2020 | Diterbitkan Online: 1-06-2020 
Pines dan Aronson (dalam Hardiyanti, 2013) mendefinisikan burnout sebagai bagian dari kelelahan fisik, emosional dan mental sebagai akibat dari keterlibatan diri dalam jangka waktu yang panjang terhadap situasi yang penuh dengan tuntutan emosional. Sedangkan (dalam Putra dan Mulyadi, 2010), menyatakan burnout adalah kondisi terperas habis dan kehilangan energi psikis maupun fisik. Biasanya hal itu disebabkan oleh situasi kerja yang tidak mendukung atau tidak sesuai dengan kebutuhan dan harapan. Kelelahan merupakan masalah yang harus mendapat perhatian. Semua jenis pekerjaan baik formal dan informal menimbulkan kelelahan kerja.

Kelelahan kerja akan menurunkan kinerja dan menambah kesalahan kerja. Menurunnya kinerja sama artinya dengan menurunnya produktivitas kerja. Apabila tingkat produktivitas seorang tenaga kerja terganggu yang disebabkan oleh faktor kelelahan fisik maupun psikis maka akibat yang ditimbulkannya akan dirasakan oleh perusahaan berupa penurunan produktivitas perusahaan.

Data dari ILO (dalam Permatasari dkk, 2017) menyebutkan hampir setiap tahun sebanyak dua juta pekerja meninggal dunia karena kecelakaan kerja yang disebabkan oleh faktor kelelahan. Penelitian tersebut menyatakan dari 58115 sampel, 32,8\% diantaranya atau sekitar 18828 sampel menderita kelelahan. Penelitian mengenai kecelakaan transportasi yang dilakukan di New Zealand antara tahun 2002 dan 2004 menunjukkan bahwa dari 134 kecelakaan fatal, 11\% diantaranya disebabkan faktor kelelahan dan dari 1703 cidera akibat kecelakaan, 6\% disebabkan oleh kelelahan pada operatoroperator. Hal ini tentu membuat para karyawan tidak aman dalam bekerja.

Ketidakamanan kerja atau dapat disebut dengan job insecurity dapat didefinisikan sebagai kondisi yang berhubungan dengan rasa takut seseorang akan kehilangan pekerjaanya atau prospek akan demosi atau penurunan jabatan serta berbagai ancaman lainnya terhadap kondisi kerja yang berasosiasi menurunnya kesejahteraan secara psikologis dan menurunnya kepuasan kerja, Pekerjaan yang berjangka pendek (kontrak) akan mengakibatkan ketidakpastian. Rowntree (dalam Hanafiah, 2014)

Menurut Green (dalam Hanafiah, 2014) job insecurity merupakan ketidakpastian yang menyertai suatu pekerjaan yang menyebabkan rasa takut atau tidak aman terhadap konsekuensi pekerjaan tersebut yang meliputi ketidakpastian penempatan atau ketidakpastian masalah gaji serta kesempatan mendapatkan promosi atau pelatihan. Ketidakamanan (job insecurity) kerja ini di timbulkan oleh beberapa faktor.

Menurut Green (dalam Hanafiah, 2014) bahwa faktor yang mempengaruhi ketidakamanan kerja (job insecurity) dipengaruhi oleh lingkungan kerja yang meliputi lingkungan kerja fisik dan lingkungan kerja psikis, kondisi di luar lingkungan kerja, dan diri pribadi. Lebih lanjut, Saylor (dalam, Hanafia, 2014) berpendapat bahwa aspek-aspek job insecurity meliputi ketakutan akan kehilangan pekerjaan, bekerja lebih keras, dan ketakutan akan kehilangan status sosial.

Berdasarkan hasil wawancara yang peneliti lakukan pada tanggal 24 Oktober 2019 kepada beberapa karyawan outsourching didapatkan bahwa dalam menjalankan pekerjaan mereka sering mengalami sakit kepala, sering mengantuk, pusing, serta tidak fokus ketika diberikan tugas. Tidak hanya itu mereka juga merasakan beberapa hal lainnya seperti mereasa bosan, mudah tersinggung, badmood, sering tidak percaya diri ketika mendapatkan tugas yang harus di selesaikan dengan tepat waktu, serta khawatir bila tugas yang diberikan tidak maksimal dan sesuai dengan apa yang di targetkan. Permasalahan ini menimbulkan dampak pada individu itu sendiri dan juga bagi perusahaan, dimana berdasarkan keterangan kepala HRD bahwa dampak yang ditimbulkan seperti team work yang kurang baik, ketika tugas yang diberikan tidak maksimal atau tidak sesuai target mereka saling menyalahkan satu sama lain, hal ini terlihat ketika saat dipanggil ke ruangan HRD dan juga pada saat rapat diskusi mereka saling menyalahkan satu sama lain dan sering menunda-nunda tugas yang diberikan.

Wawancara lebih lanjut yang dilakukan pada karyawan outsourching didapatkan juga adanya rasa takut pada karyawan yang akan masa depan mereka di kantor, mereka takut apabila posisi dan jabatan mereka tergantikan, tidak mendapatkan pekerjaan lagi, dan mereka juga takut akan kehilangan status sosial terkait dengan ketidakpastian karir. Jika permasalahan ini terus berlanjut maka yang akan terkena dampaknya tidak hanya pada diri sendiri melainkan juga terhadap organisasi atau perusahaan dimana karyawan tersebut bekerja.

\subsection{Burnout}

Burnout adalah hasil psikologis dan fisik yang parah tingkat berkepanjangan dan stres tinggi di tempat kerja. Ini biasanya terjadi di antara karyawan yang tidak mampu mengatasi tekanan pekerjaan yang 
luas yang menuntut energi, waktu, dan sumber daya, dan di antara karyawan yang bekerja membutuhkan berurusan dengan orang-orang. Para peneliti telah menemukan bahwa burnout membawa dampak yang sangat besar untuk organisasi dan individu karena dampak negatif terhadap kerja karyawan serta sikap dan mengarah ke perilaku yang tidak diinginkan, seperti keterlibatan kerja rendah, kinerja tugas berkurang, dan meningkatnya pergantian karyawan. Pada karyawan yang mengalami burnout menjadi kurang energik dan kurang tertarik dalam pekerjaan mereka. Mereka akan mengalami kelelahan secara emosional, apatis, depresi, mudah tesinggung, dan bosan. Cenderung untuk menemukan kesalahan pada segala aspek lingkungan kerja mereka, termasuk rekan kerja, dan bereaksi negatif terhadap usulan orang lain(dalam Hardiyanti, 2013). burnout adalah ekspresi dari situasi kehabisan energi, motivasi atau insentif. Yang menunjukkan perubahan sikap dan prilaku seseorang dalam menanggapi tuntutan, serta frustasi karna menganggap dirinya tidak dihargai dalam pekerjaannya (dalam Prijayanti, 2015). Burnout sebagai suatu keadaan kelelahan secara fisik, emosi dan mental yang disebabkan keterlibatan dalam jangka waktu yang panjang pada situasi yang secara emosional penuh dengan tuntutan (dalam Hartawati \& Mariyanti, 2014).

Burnout adalah fenomena yang sangat berkaitan erat dengan stress kerja. Para ahli mendefinisikan bahwa burnout adalah suatu fenomena menipisnya sumber daya fisik dan mental yang disebabkan oleh usaha yang berlebihan untuk mencapai tujuan yang berhubungan dengan pekerjaan (dalam Putri, 2014). Burnout sebagai kehilangan kekuatan fisik atau emosional dan motivasi yang biasanya sebagai akibat dari stres berkepanjangan atau frustasi, peran konflik atau ambiguitas, upah yang rendah dan kurangnya sistem penghargaan yang sehari-hari tegangan yang cenderung asah karyawan di dunia, mengakibatkan depresi dan keluar dari kerangka pikirannya (dalam Katarini, 2011).

\subsection{Dimensi Burnout}

Menurut Maslach \& Leiter (1997) menyebutkan bahwa terdapat tiga dimensi burnout, yaitu:

(a) Exhaustion, ketika pekerja merasakan kelelahan (Exhaustion), mereka cendrung berprilaku overextended baik secara emosional maupun fisikal. Mereka tidak mampu menyelesaikan masalah mereka. tetap merasa lelah meski sudah istirahat yang cukup, kurang energi dalam melakukan aktivitas (b) Cyniscism, Ketika pekerja merasakan cynicism (sinis), mereka cendrung dingin, menjaga jarak, cendrung tidak ingin terlibat dengan lingkungan kerjanya. Cyinicism juga merupakan cara untuk terhindar dari rasa kecewa. Perilaku agresif seperti ini dapat memberikan dampak yang serius pada efektivitas kerja (c) Ineffectiveness, ketika pekerja merasa tidak efektif, mereka cendrung mengembangkan rasa tidak mampu. Setiap pekerjaan terasa sulit dan tidak bisa dikerjakan, rasa percaya diri berkurang. Pekerja menjadi tidak percaya dengan dirinya sendiri dan orang lain tidak percaya dengannya.

Menurut Minner (dalam Sutrisno, 2010) mengemukakan secara umum dapat dinyatakan empat aspek dari kinerja, yaitu :mengemukakan bahwa terdapat tiga aspek dari burnout yaitu: (a) kualitas, menerangkan tentang jumlah kesalahan, waktu, dan ketepatan dalam melakukan tugas (b) kuantitas, berkenaan dengan berapa jumlah produk atau jasa yang dapat dihasilkan (c) waktu kerja, menerangkan akan berapa jumlah absen, keterlambatan, serta masa kerja yang telah dijalani individu pegawai tersebut (d) kerja sama, menerangkan akan bagaimana individu membantu atau menghambat usaha dari teman sekerjanya.

\subsection{Job Insecurity}

Ashford, Lee \& Bobko (dalam Sari 2018), menyatakan job insecurity merupakan perasaan tegang, gelisah, khawatir, stress, dan merasa tidak pasti dalam kaitannya dengan sifat dan keberadaan pekerjaan selanjutnya yang dirasakan karyawan. Job insecurity didefinisikan sebagai keadaan rasa tidak aman yangdiakibatkan oleh adanya ancaman terhadap keberlangsungan pekerjaannya. Green dan Rosenblatt (dalam Iskandar dan Yuhansyah, 2018) mendefinisikan ketidakamanan kerja sebagai perasaan tidak berdaya untuk mempertahankan kesinambungan yang diinginkan dalam situasi pekerjaan yang terancam. Pendapat lain dari De Witte (dalam Iskandar \& Yuhansyah, 2018) mengatakan bahwa ketidakamanan kerja merupakan suatu reaksi negatif karyawan terhadap perubahan yang terjadi pada pekerjaan mereka, termasuk ketakutan akan kehilangan pekerjaan mereka. Suciati (dalam Iskandar dan Yuhansyah, 2018) mengatakan bahwa ketidakamanan kerja adalah persepsi 
subyektif individu mengenai ketidakberdayaannya untuk menjaga keberlanjutan kerja dalam situasi yang mengancam. Paul dan Brijball (dalam Iskandar dan Yuhansyah, 2018) juga menjelaskan bahwa ketidakamanan kerja lebih dari sekedar dugaan kehilangan pekerjaan tapi juga mencakup pemikiran tentang kehilangan fitur pekerjaan berharga seperti gaji, status, kesempatan untuk promosi dan akses terhadap sumber daya. Seringkali individu lebih jauh mencirikan ancaman terhadap keseluruhan pekerjaan karena lebih parah daripada ancaman terhadap fitur pekerjaan., karena seseorang dapat kehilangan fitur pekerjaan seseorang namun tetap mempertahankan keanggotaan organisasinya.

\subsection{Aspek-Aspek Job Insecurity}

Aspek-aspek Job Insecurity menurut Ashford, Lee \& Bobko (dalam Sari 2018) menggabungkan aspek pertama dan kedua, lalu menggabungkan aspek ketiga dengan keempat sehingga menjadi tiga aspek, yaitu: (a) perasaan terancam pada total pekerjaan seseorang, yaitu rasa takut kehilangan dari keseluruhan pekerjaan yang dimiliki. Kehilangan pekerjaan mungkin dapat terjadi secara permanen atau seseorang mungkin dipecat, diputus kontrak kerjanya secara tiba-tiba atau dipaksa pensiun dini (pensiun terlalu awal atau tidak sesuai umur pension seharusnya). (b) Perasaan terancam terhadap tampilan kerja (job features), yaitu rasa takut kehilangan dari berbagai aspek-aspek yang mempengaruhi pekerjaan. Perubahan organisasional mungkin menyebabkan seseorang kesulitan mengalami kemajuan dan beradaptasi dalam organisasi, kesempatan mendapat promosi, bertambahnya beban kerja, mempertahankan gaji tetap, meningkatkan pendapatan, ataupun kesulitan mendapatkan insentif. (c) Powerlesnessness (Ketidakberdayaan), yaitu perasaan tidak berdaya yang mungkin berperan dalam perasaan seseorang terhadap kurangnya kontrol atau ketidakmampuan untuk mengendalikan kejadian-kejadian di lingkungan kerjanya.

\section{Metode Penelitian}

Jenis penelitian ini adalah kuantitatif korelasional dengan variabel penelitian Menurut Sugiyono (2014) variabel Dependen, Burnout (Y) dan Variabel Independen, Job Insecurity (X). Populasi pada penelitian ini adalah karyawan outsourching FIFGROUP Cabang Padang yang berjumlah 40 orang. Teknik pengambilan sampel dalam penelitian ini adalah sampling jenuh yaitu teknik penentuan sampel bila semua anggota populasi digunakan sebagai sampel.

Alat ukur yang digunakan dalam penelitian ini adalah skala Job Insecurity dan Burnout. Menurut Azwar (2014) skala merupakan perangkat pertanyaan yang disusun untuk mengungkap atribut tertentu melalui respon terhadap pertanyaan tersebut. Skala yang digunakan dalam penelitian ini adalah skala Linkert. Skala Linkert digunakan untuk mengukur sikap, pendapat, dan persepsi seseorang. Skala Linkert memiliki empat alternatif jawaban yaitu : SS (sangat sesuai), S (sesuai). TS (tidak sesuai), STS (sangat tidak sesuai), penelitian ini tidak menggunakan pilihan jawaban tengah $\mathrm{N}$ (netral), karena menurut Azwar (2016) apabila pilihan jawaban tengah atau netral disediakan, maka subjek akan cenderung memilih jawaban tengah, sehingga data mengenai perbedaan diantara subjek menjadi kurang informatif dan sikap subjek yang sebenarnya tidak dapat diketahui secara jelas. Skala penelitian ini akan melewati berbagai tahap analisis yaitu uji normalitas menggunakan KolmogorovSmirnov dilakukan untuk mengetahui data penelitian berdistribusi normal. Uji lineritas, dilakukan untuk mengetahui apakah data variabel bebas berkorelasi secara linier dengan variabel terikat. Dua variabel dikatakan mempunyai hubungan yang linier bila nilai signifikan $<0,05$.

Selain itu dilakukan uji Validitas, untuk mengetahui apakah suatu skala dapat menghasilkan data yang akurat sesuai dengan tujuan pengukurannya (Azwar, 2016). Untuk menentukan layak atau tidaknya suatu item alat ukur yang akan digunakan biasanya dilakukan uji signifikansi pada taraf $\geq 0,50$, atau jika melakukan penilaian langsung terhadap koefisien korelasi bisa digunakan batas nilai minimal kolerasi $\geq 0,30$ (Priyatno, 2018).

\section{Hasil dan Pembahasan}

Peneliti menyebarkan 40 skala Job Insecurity dan skala Burnout pada karyawan outsourching FIFGROUP Cabang Padang dan meminta kesediaan kepada para karyawan tersebut untuk dapat mengisi skala penelitian. Pengumpulan data dilakukan dengan cara membagikan secara langsung dan 
dibantu oleh PGHS FIFGROUP kepada 40 karyawan outsorching atau keseluruhannya. Sebelum pengisian skala dilakukan, peneliti terlebih dahulu menjelaskan petunjuk dan cara pengisian skala dengan baik dan benar secara singkat dan jelas.

\subsection{Hasil}

Koefisien Validitas skala Job Insecurity dengan nilai corrected item-total correlation berkisar antara 0,305 sampai dengan 0,706, dengan reabilitas 0,884 , validitas skala Burnout dengan nilai corrected item-total correlation berkisar antara 0,373 sampai dengan 0,737, dengan reabilitas 0,915 . Uji normalitas dalam penelitian ini menggunakan uji Kolmogorov-Smirnov. Priyatno (2013) menyatakan bahwa data yang dinyatakan berdistribusi normal jika signifikansi (p) lebih besar dari 0,05. Berdasarkan hasil pengolahan data dengan menggunakan program IBM SPSS 21.0, Maka diperoleh hasil sebagai berikut:

Tabel 1. Uji Normalitas Skala Job Insecurity dengan Burnout

\begin{tabular}{ccccc}
\hline Variabel & $\mathbf{N}$ & KSZ & P & Sebaran \\
\hline Job Insecurity & 40 & 0,818 & 0,516 & Normal \\
Burnout & 40 & 1,112 & 0,169 & Normal \\
\hline
\end{tabular}

Nilai signifikansi pada skala $J o b$ insecurity sebesar $\mathrm{p}=0,516$ dengan $\mathrm{KSZ}=0,818$ hasil tersebut menunjukan bahwa nilai $\mathrm{p}>0,05$, artinya sebaran skala Job Insecurity berdistribusi secara normal, sedangkan untuk skala Burnout diperoleh nilai signifikansi sebesar $\mathrm{p}=0,619$ dengan $\mathrm{KSZ}=1,112$ hasil tersebut menunjukan bahwa nilai $\mathrm{p}>0,05$, artinya sebaran terdistribusi secara normal. Selanjutnya uji linearitas dapat dilihat pada tabel 2 berikut:

Tabel 2. Uji Linieritas Job Insecurity dengan Burnout

\begin{tabular}{ccccc}
\hline $\mathbf{N}$ & Df & Mean Square & F & Sig \\
\hline 40 & 1 & 134,934 & 9,847 & 0,004 \\
\hline
\end{tabular}

Berdasarkan tabel diatas, maka diperoleh nilai $\mathrm{F}$ sebesar $=9,847$ dengan signifikans sebesar $\mathrm{p}=0,004$ ( $<<0,05)$, artinya varians pada skala Job Insecurity dan Burnout tergolong linier.

Tabel 3. Hasil Uji Korelasi Antara Job Insecurity dengan Burnout

\begin{tabular}{ccccc}
\hline $\mathbf{P}$ & $(\boldsymbol{\alpha})$ & Nilai Korelasi $(\mathbf{r})$ & R square & Kesimpulan \\
\hline 0,009 & 0.01 & 0,406 & 0,165 & $\begin{array}{c}\text { sig (2-tailed) } 0,009<0,01 \text { level of } \\
\text { significant }(\alpha), \text { berarti hipotesis } \\
\text { diterima. }\end{array}$ \\
\hline
\end{tabular}

Berdasarkan hasil pengolahan data Job Insecurity dengan Burnout, dengan jumlah sampel penelitian sebanyak 40 karyawan outsourching, maka diperoleh nilai koefisien (r) sebesar $=0,406$ dan nilai $\mathrm{p}=$ $0,009<0,01$ level of significant (a), artinya hipotesis diterima, Hal ini menunjukan bahwa terdapat hubungan yang positif antara Job Insecurity dengan Burnout pada karyawan outsourching FIFGROUP Cabang Padang. Nilai positif menunjukan bahwa semakin tinggi Job Insecurity maka semakin tinggi juga Burnout pada karyawan, sebaliknya semakin rendah Job Insecurity maka semakin rendah Burnout.

Tabel 4. Descriptive Statistic

\begin{tabular}{cllccc}
\hline Variabel & N & Mean & Std. Deviation & Minimum & Maximum \\
\hline Job Insecurity & 40 & 36,78 & 3,873 & 29 & 45 \\
Burnout & 40 & 50,55 & 4,579 & 41 & 64 \\
\hline
\end{tabular}

Berdasarkan nilai mean hipotetik tersebut, maka dapat dilakukan pengelompokan yang mengacu pada kriteria pengkategorisasian dengan tujuan menempatkan individu ke dalam kelompok-kelompok yang terpisah secara berjenjang menurut suatu kontinum berdasarkan atribut yang diukur (Azwar, 2014). 
Untuk menentukan dan mengetahui gambaran Job insecurity dengan Burnout, dapat dibagi dalam tiga kategori yaitu tinggi, sedang, rendah. Menurut Azwar (2014) klasifikasi skor jawaban penelitian menggunakan tiga kategori dijelaskan dalam rumus sebagai berikut :

Tabel 5. Kategori Job Insecurity dengan Burnout

\begin{tabular}{ccccc}
\hline Variabel & Skor & Jumlah & Persentase (\%) & Kategori \\
\hline \multirow{2}{*}{ Job Insecurity } & $29-32$ & 5 & $12 \%$ & Rendah \\
& $33-40$ & 29 & $72 \%$ & Sedang \\
& $41-45$ & 6 & $15 \%$ & Tinggi \\
Burnout & $41-45$ & 6 & $15 \%$ & Rendah \\
& $46-55$ & 32 & $80 \%$ & Sedang \\
& $56-64$ & 2 & $5 \%$ & Tinggi \\
\hline
\end{tabular}

Berdasarkan tabel diatas, maka dapat diperoleh variabel Job Insecurity dengan gambaran bahwa 5 orang dengan $12 \%$ Job Insecurity pada kategori rendah, 29 orang dengan $72 \%$ berada pada kategori sedang, dan 6 orang dengan 15\%, berada pada kategori tinggi, sedangkan untuk variabel Burnout diperoleh gamabaran bahwa 6 orang dengan $15 \%$ memiliki Burnout berada pada kategori rendah, 32 orang dengan $80 \%$ berada pada kategori sedang, dan 2 orang dengan $15 \%$ karyawan memiliki Burnout pada kategori tinggi

Besar kecilnya sumbangan efektif dari Job Insecurity terhadap Burnout dapat ditentukan dengan menggunakan rumus koefisien determinan. Koefisien determinan adalah kuadrat dari koefisien korelasi yang dikali dengan 100\%. Adapun sumbangan efektif dari variabel job insecurity dan burnout adalah sebesar $16 \%$ dan $84 \%$ di pengaruhi oleh faktor lain diantaranya, eksternal, personal, dan demografis, Caputo (dalam Putri, 2014).

\subsection{Pembahasan}

Berdasarkan hasil uji korelasi product moment pearson yang dilakukan dengan bantuan IBM SPSS versi 21.0, diperoleh nilai koefisien korelasi $\mathrm{r}=0,406$ dengan nilai $\mathrm{p}=0,009$, karena nilai (p) sig $0,009<0,01$ maka hipotesis diterima. Hasil ini menunjukkan bahwa terdapat hubungan yang positif antara job insecurity dengan burnout pada karyawan outsourching FIFGROUP Cabang Padang, artinya semakin tinggi job insecurity maka semakin rendah juga burnout yang terjadi pada karyawan khususnya karyawan yang berstatus sebagai karyawan outsourching, sebaliknya semakin rendah job insecurity, maka semakin tinggi burnout yang tinggi burnout yang akan diterima oleh karyawan outsourching.

Hasil uji hipotesis tersebut bahwa salah satu faktor yang menyebabkan individu mengalami burnout adalah job insecurity. Guillermo (dalam M. Ramdhan \& Oktaviana Nursan Fadly, 2016) yang menyatakan bahwa status tenaga kontrak / honorer sering menjadi penyebab burnout dihubungkan dengan job insecurity, perasaan tidak aman dalam bekerja atau ancaman akan kehilangan pekerjaan. Sama dengan Smithson dan Lewis (dalam M. Ramdhan \& Oktaviana Nursan Fadly, 2016) yang sependapat bahwa job inscurity adalah kondisi psikologis karyawan yang menunjukkan perasaan bingung dan merasa tidak aman dikarenakan kondisi lingkungan kerja yang berubah-rubah. Kondisi ini muncul sebagai akibat jenis pekerjaan yang tidak permanen (pekerja kontrak). Berbeda dengan pegawai negeri sipil yang merasa tenang dalam bekerja karena kemungkinan kehilangan pekerjaan hampir tidak ada.

Hasil ini sesuai dengan penelitian Ismail dalam (dalam M. Ramdhan \& Oktaviana Nursan Fadly, 2016), yang menyimpulkam Job Insecurity berhubungan dengan burnout. Oleh karena itu hal ini semakin memperkuat bahwa salah satu yang mempengaruhi Burnout adalah Job Insecurity. semakin tinggi Job Insecurity maka semakin tinggi pula Burnout yang diterima, sebaliknya semakin rendah rendah Job Insecurity maka semakin rendah pula Burnout.

Berdasarkan hasil yang telah didapatkan, maka dapat diperoleh variabel job insecurity dengan gambaran bahwa 5 orang dengan 12\% job insecurity pada kategori rendah, 29 orang dengan $72 \%$ berada pada kategori sedang, dan 6 orang dengan 15\%, berada pada kategori tinggi, sedangkan untuk variabel burnout diperoleh gamabaran bahwa 6 orang dengan $15 \%$ memiliki burnout berada pada 
kategori rendah, 32 orang dengan $80 \%$ berada pada kategori sedang, dan 2 orang dengan $15 \%$ karyawan memiliki burnout pada kategori tinggi.

Adapun sumbangan efektif dari variabel job insecurity dan burnout adalah sebesar $16 \%$ dan $84 \%$ di pengaruhi oleh faktor lain diantaranya, eksternal, personal, dan demografis, Caputo (dalam Putri, 2014).

\section{Kesimpulan}

Berdasarkan hasil penelitian yang telah dilakukan, maka dapat ditarik kesimpulan yang sekaligus merupakan jawaban dari tujuan penelitian, yaitu : Berdasarkan uji korelasi terdapat hubungan antara job insecurity dengan burnout pada karyawan outsourching FIFGROUP Cabang Padang. Dimana semakin tinggi job insecurity maka semakin tinggi pula burnout yang diterima, sebaliknya semakin rendah job insecurity maka semakin rendah pula burnout pada karyawan outsourching FIFGROUP, artinya hipotesis diterima. Adapun sumbangan efektif dari variabel job insecurity dan burnout adalah sebesar $16 \%$.

\section{Daftar Rujukan}

Azwar, Saifuddin. (2016). Penyusunan Skala Psikologi. Yogyakarta: Pustaka Pelajar.

Hadiyanti, Ranni. (2013). "Burnout Ditinjau Dari Big Five Factors Personality Pada Karyawan Kantor Pos Pusat Malang”. Jurnal ilmiah psikologi terapan. Fakultas Psikologi, Universitas Muhammadiyah Malang, Vol. 01, No.02, ISSN: 2301-8267.

Hanafiah, Mohammad. (2014). "Pengaruh Kepuasan Kerja Dan Ketidakamanan Kerja (Job Insecurity) Dengan Intensi Pindah Kerja (Turnover) Pada Karyawan Pt. Buma Desa Suaran Kecamatan Sambaliung Kabupaten Berau". ejournal Psikologi, Volume 1, Nomor 3, 2014: 303-312.

Hartawati, Dewi \& Sulis Mariyanti. (2014). "Hubungan Antara Self Efficacy Dengan Burnout Pada Pengajar Taman Kanak-Kanak Sekolah X Di Jakarta. Jakarta. Jurnal Psikologi Volume 12 Nomor 2, Desember 2014.

Iskandar \& Yuhansyah. (2018). "Pengaruh Motivasi \& Ketidakamanan Kerja Terhadap Penilaian Kerja Yang Berdampak Kepada Kepuasan Kerja". Samarinda. Media Sahabat Cendekia.

Katarini, Nikki Rasuna. (2011). "Burnout Pada Karyawan Ditinjau Dari Persepsi Budaya Organisasi Dan Motivasi Intrinsik Di PT. KRAKATAU STEEL. Skripsi. Fakultas Kedokteran Universitas Sebelas Maret Surakarta.

Markus, Viestar Jeffrian \& Devi Jatmika. (2017). "Hubungan Antara Job Insecurity Dan Komitmen Organisasi Pada Karyawan PT. KX”. Jakarta utara. Jurnal Psikologi Ulayat, Vol. 4, No. 1/Juni 2017, hlm. 83-9.

Maslach, Ctristina \& Michael P. Leiter. (1997). "The Truth About Burnout" San Fransisco. Jossey-Bass.

M. Ramdhan, Iwan \& Oktavian Nursan Fadly. (2016). Analisis Faktor Yang Berhubungan Dengan Burnout Pada Perawat Kesehatan Jiwa. Samarinda. Vol. 4, No 2 Agustus 2016.

Permatasari, Anjar, Farit Rezal \& Sabril Mundandar. (2017). "Faktor Yang Mempengaruhi Hubungan Dengan Kelelahan Kerja Pada Karyawan Di Matahari Departemen Store Cabang Lippo Plaza Kendari Tahun 2016”. Kendari. Jurnal Ilmiah Mahasiswa Kesehatan Masyarakat Vol. 2/No.5/ Januari 2017 ; ISSN 250-731X.

Prestiana, Novita Dian Iva \& Trias Xandria Andari Putri. (2013). "Internal Locus Of Control Dan Job Insecurity Terhadap Burnout Pada Guru Honorer Sekolah Dasar Negeri Di Bekasi Selatan. Jurnal Soul, Vol. 6, No.1, Maret 2013.

Prijayanti, Isnia. (2015). "Pengaruh Beban Kerja Dan Dukungan Sosial Terhadap Burnout Pada Karyawan PT.X. Skripsi. Fakultas Psikologi Universitas Islam Negeri Syarif Hidayatullah.

Priyatno, Duwi. (2017). Panduan Praktis Olah Data Menggunakan SPSS. Yogyakarta: Andi

Puspitasari, Dita Ayu \& Muryantinah Mulyo Handayani. (2014). "Hubungan Tingkat Self-Efficacy Guru Dengan Tingkat Burnout Pada Guru Sekolah Inklusif Di Surabaya". Jurnal Psikologi Pendidikan dan Perkembangan Vol. 3, No. 1, April 2014.

Putra, Yanuar Surya \& Hari Mulyadi. (2010). "Pengaruh Faktor Job Demand Terhadap Kinerja Dengan Burnout Sebagai Variabel Moderating Pada Karyawan Bagian Produksi Pt.Tripilar Betonmas Salatiga". Among Makarti, Vol.3 No.6, Desember 2010.

Putri, Dissy Viana Andani (2014). "Analisis Pengaruh Dukungan Sosial terhadap Burnout pada Perawat". Skripsi. Fakultas Ekonomika Dan Bisnis Universitas Diponegoro Semarang.

Sari, Ratih Puspita. (2018). "Pengaruh Job Insecurity Terhadap Komitmen Organisai" Pada Karyawan PT. PUU. Skripsi. Fakultas Psikologi Universitas Sumatera Utara.

Sugiyono. (2014). Metode Penelitian Kuantitatif Kualitatif dan R\&D. Bandung: Alfabeta.

Psyche 165 Journal Terakredetasi Sinta 5 